\title{
Interleukin-19 enhances cytokine production induced by lipopolysaccharide and inhibits cytokine production induced by polyl:C in BALB/c mice
}

\author{
Yasu-Taka AZUMA ${ }^{1 \text { )* }}$ and Kazuhiro NISHIYAMA ${ }^{1)}$ \\ 1)Laboratory of Veterinary Pharmacology, Division of Veterinary Science, Osaka Prefecture University Graduate \\ School of Life and Environmental Sciences, Izumisano, Osaka 598-8531, Japan
}

\begin{abstract}
Interleukin (IL)-19 is a cytokine of the IL-10 family. There are many reports on the involvement of IL-19 in several human diseases. There also are many reports elucidating the role of IL-19 using mouse disease models. Most reports use C57BL/6 mice, whereas few reports use $\mathrm{BALB} / \mathrm{c}$ mice, in terms of the mouse disease model that the researchers used in the present study. To date, research on the role of IL-19 is diversified, yet some basic mechanisms are still unclear. In this study, we administered lipopolysaccharide (LPS), polyl:C, and CpG to BALB/c mice, measured more than 20 cytokines in the blood and compared them with that of the wild-type and IL-19deficient (IL-19 KO) mice. LPS is associated with bacterial infection, polyl:C is associated with viral infection, and $\mathrm{CpG}$ is associated with both bacterial and viral infections. Among the cytokines measured, the results of experiments using LPS revealed that the production of some cytokines was suppressed in IL-19 KO mice. Interestingly, the experiments using polyl:C revealed that production of some cytokines was enhanced in IL-19 KO mice. However, the experiments using CpG have shown that the production of only one cytokine was enhanced in IL-19 KO mice. These results revealed that cytokine production in the blood was regulated by IL-19, and the type of regulation was dependent on the administered stimulant.
\end{abstract}

J. Vet. Med. Sci.

82(7): 891-896, 2020

doi: 10.1292/jvms.20-0137

Received: 11 March 2020

Accepted: 26 April 2020

Advanced Epub: 7 May 2020
KEY WORDS: BALB/c mouse, interleukin-19, lipopolysaccharide, polyl:C, serum

Interleukin (IL)-19 was discovered in 2000 [13]. In the last 20 years of research, IL-19 was found to be primarily involved in Th1-mediated diseases, such as psoriasis [14, 20], rheumatism [23], and Crohn's disease [4, 10, 25, 31]. Furthermore, IL-19 is also involved in Th2-mediated diseases, such as atopic dermatitis [12], asthma [32], and ulcerative colitis [4, 10, 11, 31]. In addition, IL-19 is involved in brain inflammation [16], renal disorders [19], vascular disorders [6], cancer [17], tuberculosis [21], and parasitic infections [1]. IL-19 is an important cytokine that is proinflammatory or anti-inflammatory depending on the type of organ or disease. As described above, IL-19 plays a functional role in a wide range of organs throughout the body, but its basic mechanisms are still unclear. One of them is the result of a research on the differences in the genetic background of mice. In general, C57BL/6 mice are commonly used in experiments, although BALB/c mice are also a major experimental animal strain. $\mathrm{BALB} / \mathrm{c}$ mice show a Th2-dominant response to parasite infection or exogenous antigen challenge, whereas C57BL/6 mice show a Th1-dominant response to the same stimulus [28]. However, BALB/c mice do not always exhibit Th2-type responses, and C57BL/6 mice are not always committed to Th1-type responses [26, 28]. The phenotypes of both mice differ depending on the stimulus and experimental conditions. In immunology research, experiments using both strains are expected when it has potential application to humans. Several previous reports of IL-19 in mice have mostly used C57BL/6 mice, and only four papers by other authors $[5,18,22,33]$ and two of our previous studies $[11,12]$ have used BALB/c mice. We pride ourselves on leading IL-19 research, and we hope that our research results using BALB/c mice will lead to a better understanding of the role of IL-19 in the future.

The invasion of microorganisms, such as bacteria, viruses, parasites, and fungi, releases pro- and anti-inflammatory cytokines into the body. Exogenous substances associated with pathogenic microorganisms, such as lipopolysaccharide (LPS), which lead to cytokine production are called pathogen-associated molecular patterns (PAMPs). Cytokine production in response to PAMPs is part of the host defenses, but positive feedback of cytokines and leukocytes can cause a serious condition called a cytokine storm, which can trigger a possibly fatal immune response [34]. The role of IL-19 in cytokine production in the blood has never been 
clarified. Therefore, we compared the cytokine production in the blood after PAMPs administration to BALB/c wild-type (WT) mice and IL-19-deficient (IL-19 KO) mice back-crossed to BALB/c mice. IL-19 is mainly produced from macrophages [3]. Of the cytokines produced by macrophages, involved in macrophage chemotaxis, and involved in Th1/Th2 balance, 22 kinds of cytokines were examined. LPS is a Toll-like receptor (TLR) 4 ligand involved in bacterial infection, polyI:C is a TLR3 ligand involved in viral infection, and CpG is a TLR9 ligand that promotes the activation of B cells and plasma cells.

\section{MATERIALS AND METHODS}

\section{Mice}

We used IL-19KO mice on a BALB/c background [11, 12]. Heterozygous mice were crossed to produce IL-19KO and WT control mice. All mice used were 12-15 weeks old. We studied male mice. All animal protocols were approved by the Osaka Prefecture University Animal Care and Committee.

\section{Drugs}

LPS (Escherichia coli 0111:B4), polyI:C (high molecular weight), and CpG ODN 1668 (type B CpG oligonucleotide) was all obtained from InvivoGen (San Diego, CA, USA). For in vivo studies drugs were dissolved in $0.89 \% \mathrm{NaCl}$ (saline) and administered via the intraperitoneal (i.p.) route in an injection volume of $10 \mathrm{ml} / \mathrm{kg}$, and saline was administered alone as a vehicle to control animals.

\section{Administration and cytokine analysis}

The mice were injected with either LPS ( $3 \mathrm{mg} / \mathrm{kg})$, polyI:C ( $5 \mathrm{mg} / \mathrm{kg}), \mathrm{CpG}(100 \mathrm{nmol} / \mathrm{kg})$, or saline, returned to their home cage, and decapitated through cervical dislocation $2 \mathrm{hr}$ after treatment. Trunk blood was obtained by exsanguination, centrifuged at $800 \mathrm{~g}$ at $4^{\circ} \mathrm{C}$ for $15 \mathrm{~min}$, and the resultant serum was frozen immediately and stored at $-80^{\circ} \mathrm{C}$ until use. The cytokine concentrations in the blood were determined using ELISA (catalog BMS606INST, BMS614INST, BMS607/2INST, BMS6002INST, BMS613INST; eBioscience, San Diego, CA, USA) and multiplex assays (catalog M60-009RDPD; Bio-Rad, Hercules, CA, USA) according to the manufacturer's instructions.

\section{Statistical analysis}

Error bars indicate the SEM. Statistical significance for nonrepeated measures, which is indicated by \#, was determined by one-way ANOVA, and the Tukey-Kramer test was used to detect the differences among the four groups of drug administration in WT or IL-19 KO mice. The statistical significance of the parametric data, which is indicated by *, was determined using two-tailed Student's $t$-test to detect the differences between WT and IL-19 KO mice. A $P$ value of less than 0.05 was considered statistically significant.

\section{RESULTS}

\section{Increased cytokines in LPS administration}

Figure 1 shows the results for IL-1 $\alpha$, IL-13, IFN- $\gamma$, and G-CSF. All four cytokines showed significant increases in WT mice after LPS administration, whereas no significant change was observed in WT mice after polyI:C administration and CpG administration. In addition, the increase of cytokine levels in LPS-administered WT mice was similar in LPS-administered IL-19 KO mice, without evidence of IL-19 gene deficiency. G-CSF did not increase in WT mice after CpG administration, and IL-19 KO mice showed a significant increase in cytokine level compared with WT mice.

\section{LPS-induced cytokines were suppressed by IL-19 KO}

Figure 2 shows the results for IL-2, IL-4, IL-10, IL-12 p70, IL-13, TNF- $\alpha$, GM-CSF, and CCL11. Similar to Fig. 1, the eight cytokines on this figure showed a significant increase only in WT mice after LPS administration. In addition, the increased cytokine production in WT mice after LPS administration was significantly suppressed in IL-19 KO mice in all eight cytokines.

\section{Cytokine production was increased by LPS, polyI:C and CpG administration}

Figure 3 shows the results for IL-1 $\beta$, CCL3, CCL4, IL-6, IL-12p40, CCL5, CCL2, and CXCL1. Regarding IL-1 $\beta$, CCL3, CCL4, and CCL2, their increase in WT mice after LPS administration was significantly suppressed in IL-19 KO mice. In contrast, the increase in IL-6, IL-12p40, CCL5 and CXCL1 in WT mice after LPS administration was similar to that in IL-19 KO mice. The results in this figure were similar to Fig. 1.

IL-1 $\beta$, CCL3, and CCL4 were significantly increased in WT mice after polyI:C administration, and the increase observed in WT mice after polyI:C administration was similar to that in IL-19 KO mice. Interestingly, the increased IL-6, IL-12p40, CCL5, CCL2 and CXCL1 levels demonstrated by WT mice after polyI:C administration was significantly enhanced in IL-19 KO mice.

IL-1 $\beta$, CCL3, CCL4, IL-6, IL-12p40, CCL5, and CCL2 were significantly increased in WT mice after CpG administration; however, the increase was similar in IL-19 KO mice for these seven cytokines. Interestingly, the increased CXCL1 level in WT mice after $\mathrm{CpG}$ administration was significantly increased in IL-19 KO mice.

Finally, there was no significant change in IL-5 and IL-17A after PAMPs administration (Fig. 4). 

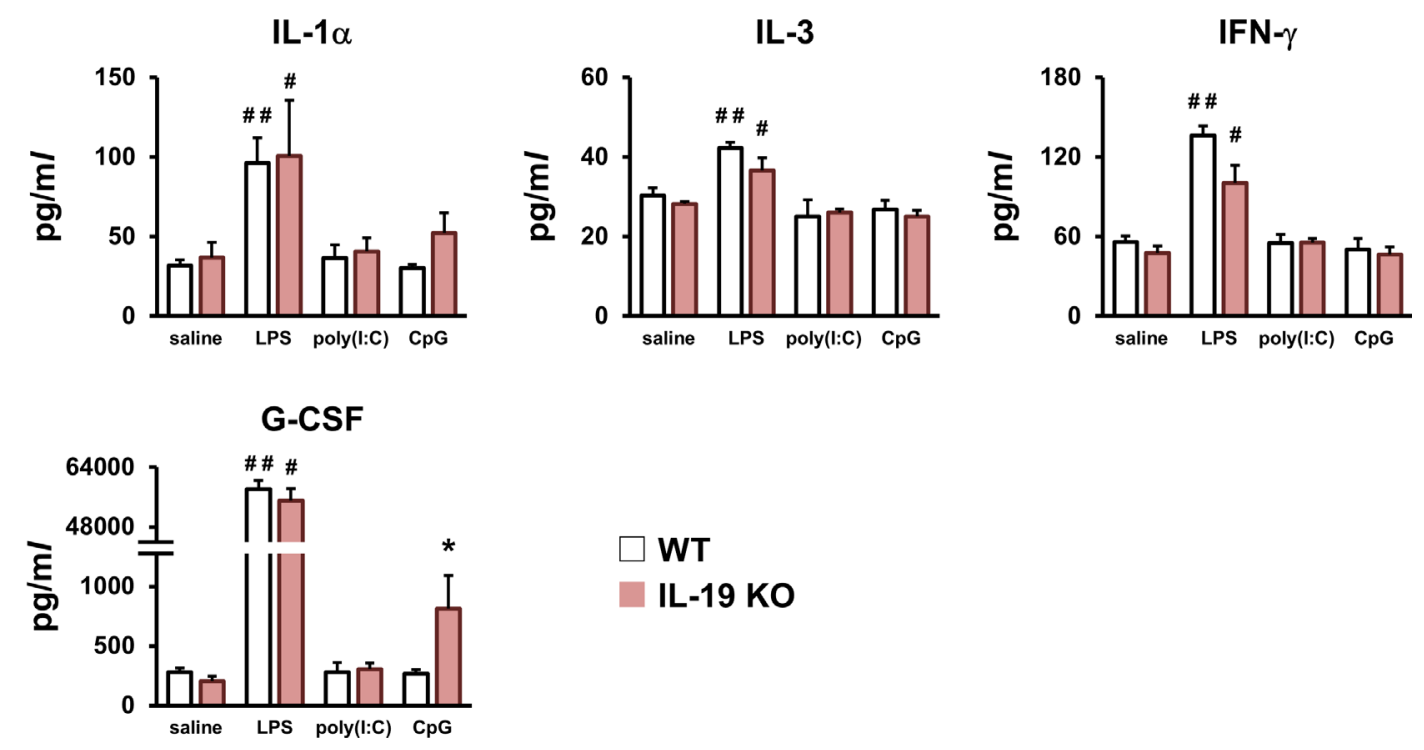

Fig. 1. Increased interleukin (IL)-1 $\alpha$, IL-3, IFN- $\gamma$ and G-CSF in lipopolysaccharide (LPS) administration. LPS, polyI:C, and CpG was administered to wild-type (WT) $(n=5)$ and IL-19 KO $(n=5)$ mice and the mice were sacrificed $2 \mathrm{hr}$ after injection. The cytokine concentrations in the serum were measured using ELISA and multiplex assays. ${ }^{\#} P<0.05,{ }^{\#} P<0.01$ compared with saline. ${ }^{*} P<0.05$, compared with WT mice.

IL-2

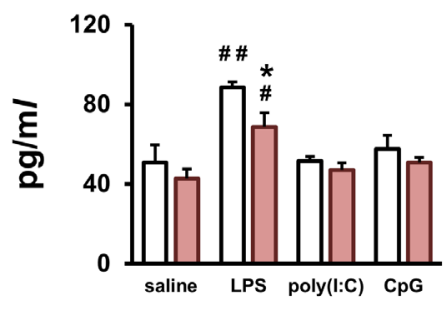

IL-12 p70

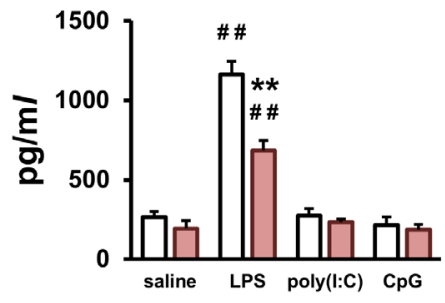

GM-CSF

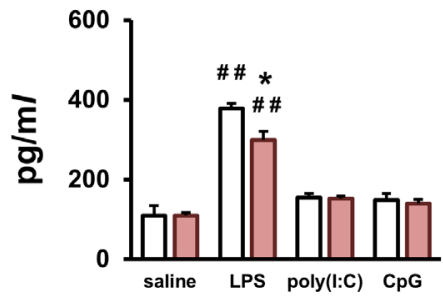

IL-4

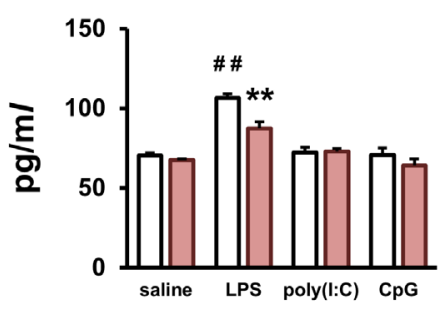

IL-13

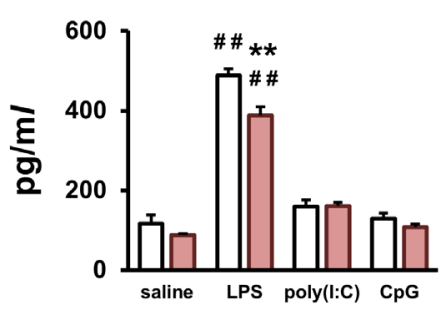

CCL11

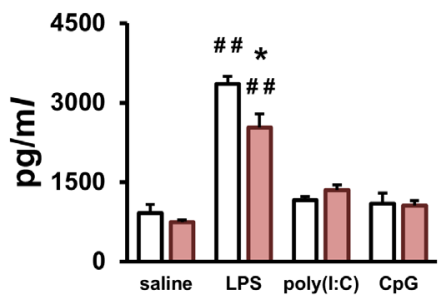

IL-10

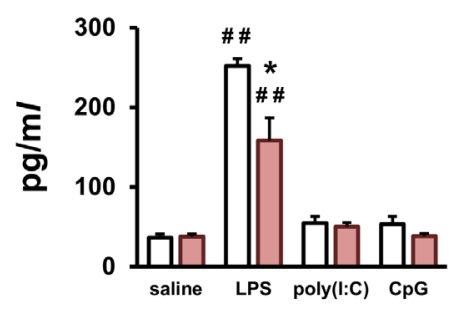

TNF- $\alpha$

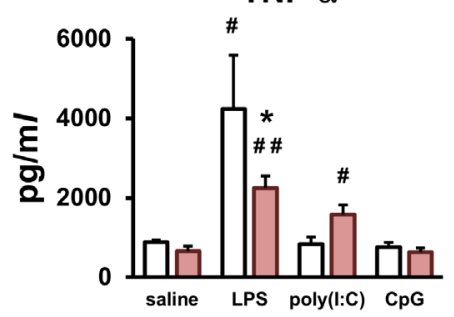

$\square$ WT

IL-19 KO

Fig. 2. Lipopolysaccharide (LPS)-induced cytokines were suppressed in IL-19 KO. LPS, polyI:C, and CpG was administered to wild-type (WT) $(n=5)$ and IL-19 KO (n=5) mice and the mice were sacrificed $2 \mathrm{hr}$ after injection. The cytokine concentrations in the serum were measured using ELISA and multiplex assays. ${ }^{\#} P<0.05,{ }^{\#} P<0.01$ compared with saline. ${ }^{*} P<0.05,{ }^{* *} P<0.01$ compared with WT mice. 

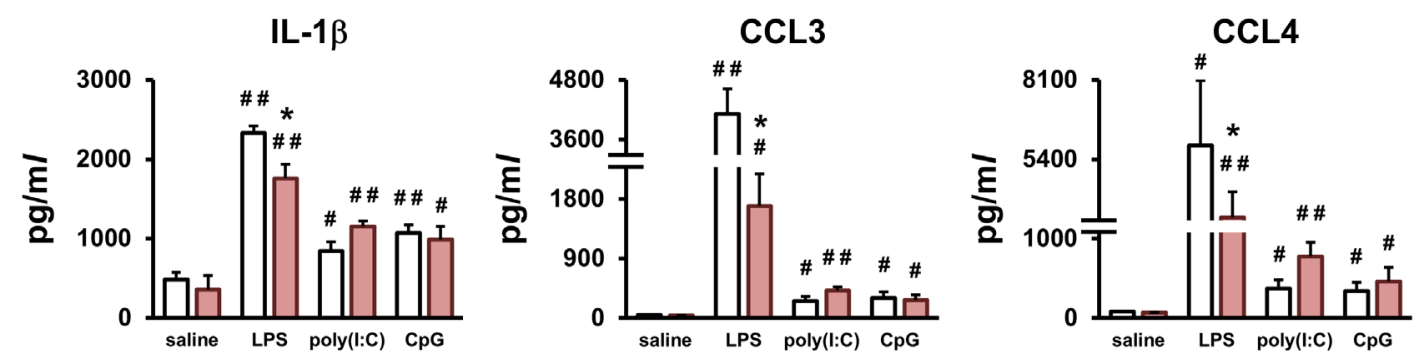

IL-6

\section{IL-12 p40}
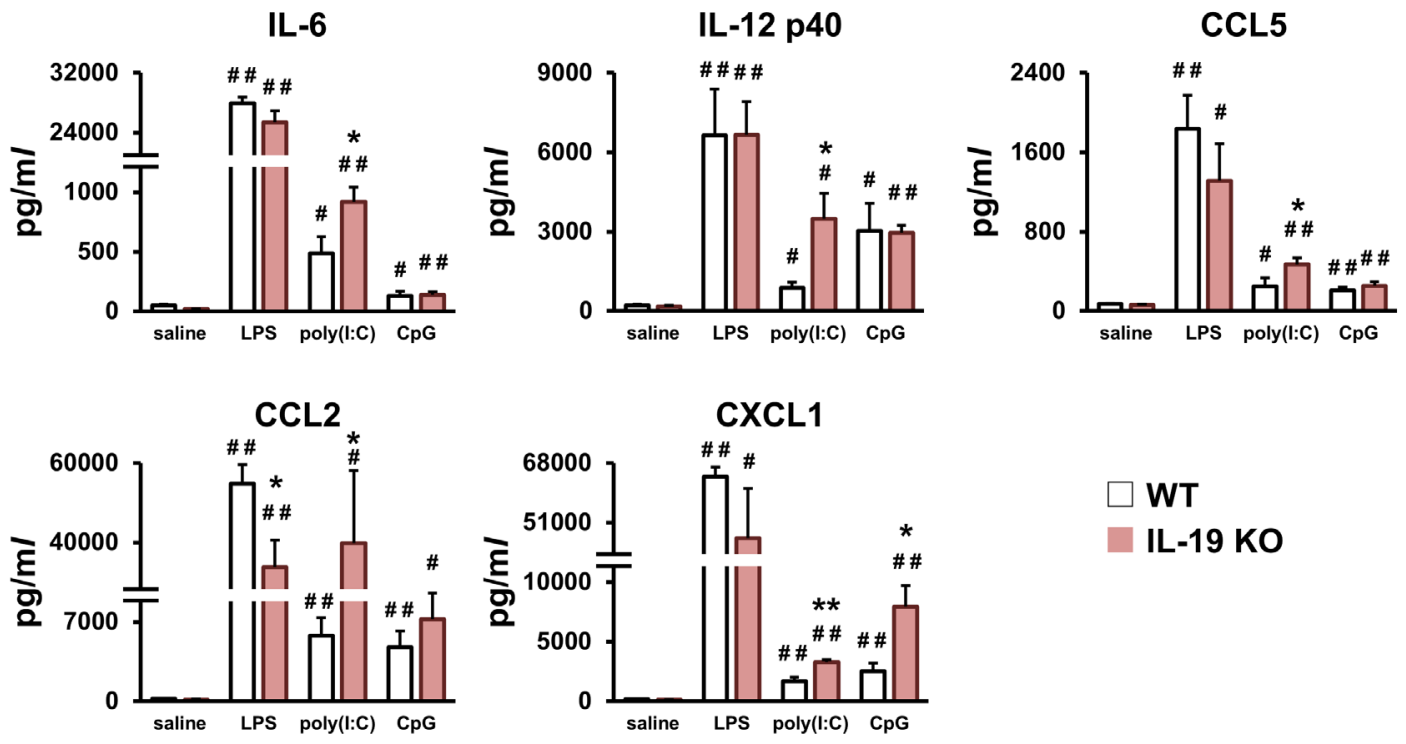

Fig. 3. Cytokines that were increased by the administration of lipopolysaccharide (LPS), polyI:C, and CpG. LPS, polyI:C and CpG was administered to wild-type (WT) $(n=5)$ and IL-19 KO $(n=5)$ mice and the mice were sacrificed $2 \mathrm{hr}$ after injection. The cytokine concentrations in the serum were measured using ELISA and multiplex assays. ${ }^{\#} P<0.05,{ }^{\#} P<0.01$ compared with saline. $* P<0.05, * * P<0.01$ compared with WT mice.

IL-5

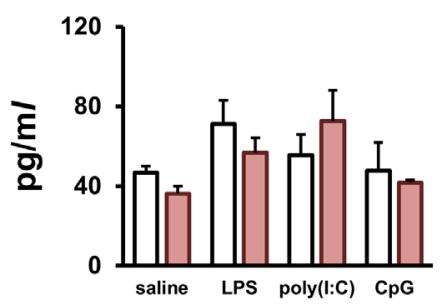

IL-17A

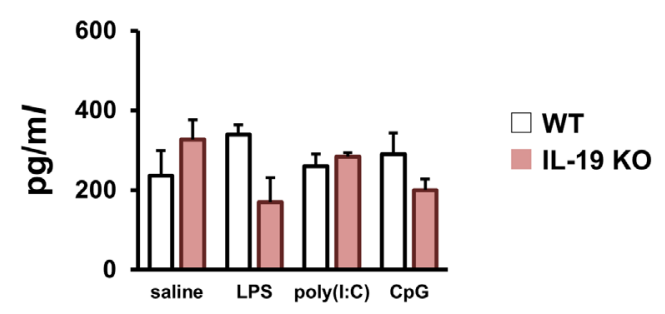

Fig. 4. No altered cytokines. Lipopolysaccharide (LPS), polyI:C, and CpG was administered to wild-type (WT) (n=5) and IL-19 $\mathrm{KO}(\mathrm{n}=5)$ mice and the mice were sacrificed $2 \mathrm{hr}$ after injection. The cytokine concentrations in the serum were measured using ELISA and multiplex assays.

\section{DISCUSSION}

This study offers new insights into the role of IL-19 based on PAMPs-induced cytokine production that leads to endotoxin shock and cytokine storm pathogenesis. Also, the study was conducted with the purpose of elucidating the role of IL-19 in BALB/c mice. In this study, we found that the serum levels of some cytokines were upregulated or downregulated in IL-19 KO mice.

The injection of LPS into experimental mice caused pathophysiological changes similar to those seen in human septic shock syndrome, with lethal endotoxemia being widely used as an experimental model of Gram-negative endotoxin shock [18]. Leukocyte recruitment to the lung and liver tissues is a hallmark of severe sepsis in humans [15, 30]. The experiments with LPS administration showed that CCL2 and CCL4 were induced and had a higher suppression rate in IL-19 KO mice (Fig. 3). The top five cytokines with high suppression rates in IL-19 KO mice are as follows: CCL3, TNF- $\alpha$, CCL4, IL-12p70, and CCL2 (Figs. 2 
and 3). This result suggests that these five cytokines are tightly regulated by IL-19. One characteristic of LPS is that the its effect was suppressed or unchanged in IL-19 KO mice, since no further significant change was observed in this group. This fact implies that IL-19 plays a role in enhancing the production of cytokines that respond to LPS. In the LPS-administered group, IL-19 KO mice exhibited significantly decreased levels of 12 types of cytokines. The types of cytokines that were decreased indicate that several cytokines are mainly involved in the inflammatory process.

PolyI:C is a synthetic RNA analog that mimics viral RNA and stimulates the production of type I interferons and inflammatory cytokines from a variety of cells, including macrophages, dendritic cells, and epithelial cells [24]. As a result, natural killer (NK) cell activation, antibody production, and killer $\mathrm{T}$ cell activation are induced. The experiments involving polyI: $\mathrm{C}$ administration showed that inflammatory cytokines, such as IL-1 $\beta$, IL-6, and IL-12p40, and several chemokines were induced in WT mice (Fig. 3). Among them, IL-6, IL-12p40, CCL5, CCL2, and CXCL1 showed further increases in production in IL-19 KO mice (Fig. 3). Of note is the increase of CCL2 and CCL5, which are chemokines involved NK cell activation that play important roles in viral infection [27, 29]. IL-6, IL-12p40, and CXCL1, however, are generally involved in inflammation. This may be due to the fact that IL-19 disrupts host defense responses by inhibiting the production of cytokines that respond to polyI:C.

CpG is a ligand for TLR9 and has an DNA sequence in which cytosine and guanine are linked by a phosphodiester bond, and is abundant in a region called CpG island [7]. However, in mammals, CpG is methylated and does not become a ligand for TLR9. On another note, bacterial and viral DNA has an unmethylated CpG DNA and is a ligand for TLR9. The synthetic CpG that was used in this study is unmethylated CpG DNA, which effectively activates the TLR9 signaling pathway. CpG stimulates the production of type I interferons and inflammatory cytokines, such as IL-12 and IL-15 [9]. Interestingly, the eight cytokines that increased with $\mathrm{CpG}$ administration were exactly the same compared with those of polyI:C (Fig. 3). This fact is very interesting and suggests that cytokines had a similar effect in downstream of TLR3 and TLR9 signaling in BALB/c mice. However, determining this requires further experimentation in future studies. On another note, the cytokines affected by IL-19 deficiency were quite different between polyI:C and CpG. Only CXCL1 showed a further increase in production in IL-19 KO mice (Fig. 3). In addition, G-CSF did not increase in WT mice after CpG administration, but IL-19 KO mice showed increased production (Fig. 1). CXCL1 functions as a chemoattractant in neutrophils [8]. Therefore, it is suggested that IL-19 may be involved in neutrophil infiltration and differentiation, which is influenced by $\mathrm{CpG}$ activation.

The differences in the role of IL-19 in C57BL/6 and BALB/c mice are still to be determined. Although there are no direct reports of similar experiments using C57BL/6 mice, there are several reports that are helpful in the experimentation phase of this study. We reported that IL-19 KO mice on C57BL/6 background showed severe phenotype upon DSS-induced colitis [2]. This severe phenotype is correlated with the increased production of IL-1 $\beta$, IL-6, IL-12, TNF- $\alpha$, IFN- $\gamma$, and CXCL1 [2]. In addition, we also reported that macrophages from IL-19 KO mice on C57BL/ 6 background produced significantly higher levels of IL- 6 , TNF- $\alpha$ and IL-12 than that of the macrophages in C57BL/6 WT mice when they were stimulated with LPS [2]. These results suggest that IL-19 may suppress the LPS response in C57BL/6 mice while enhancing the LPS response in BALB/c mice. However, the exact mechanism behind this difference requires further research.

In summary, IL-19 was observed to potentiate the LPS response while inhibiting the polyI:C response in BALB/c mice. We hope that the role of IL-19 will be further elucidated using BALB/c mice as well as C57BL/6 mice.

CONFLICT OF INTEREST. The authors declare that they have no conflicts of interest to declare.

ACKNOWLEDGMENT. This work was supported by a Grant-in-Aid for Scientific Research (B) 25292174 (Y.T.A.).

\section{REFERENCES}

1. Anuradha, R., George, P. J., Hanna, L. E., Kumaran, P., Chandrasekaran, V., Nutman, T. B. and Babu, S. 2014. Expansion of parasite-specific CD4+ and CD8+ T cells expressing IL-10 superfamily cytokine members and their regulation in human lymphatic filariasis. PLoS Negl. Trop. Dis. 8: e2762. [Medline] [CrossRef]

2. Azuma, Y. T., Matsuo, Y., Kuwamura, M., Yancopoulos, G. D., Valenzuela, D. M., Murphy, A. J., Nakajima, H., Karow, M. and Takeuchi, T. 2010. Interleukin-19 protects mice from innate-mediated colonic inflammation. Inflamm. Bowel Dis. 16: 1017-1028. [Medline] [CrossRef]

3. Azuma, Y. T., Nakajima, H. and Takeuchi, T. 2011. IL-19 as a potential therapeutic in autoimmune and inflammatory diseases. Curr. Pharm. Des. 17: 3776-3780. [Medline] [CrossRef]

4. Cantó, E., Garcia Planella, E., Zamora-Atenza, C., Nieto, J. C., Gordillo, J., Ortiz, M. A., Metón, I., Serrano, E., Vegas, E., García-Bosch, O., Juárez, C. and Vidal, S. 2014. Interleukin-19 impairment in active Crohn's disease patients. PLoS One 9: e93910. [Medline] [CrossRef]

5. Curtin, N. M., Mills, K. H. and Connor, T. J. 2009. Psychological stress increases expression of IL-10 and its homolog IL-19 via beta-adrenoceptor activation: reversal by the anxiolytic chlordiazepoxide. Brain Behav. Immun. 23: 371-379. [Medline] [CrossRef]

6. Ellison, S., Gabunia, K., Richards, J. M., Kelemen, S. E., England, R. N., Rudic, D., Azuma, Y. T., Munroy, M. A., Eguchi, S. and Autieri, M. V. 2014. IL-19 reduces ligation-mediated neointimal hyperplasia by reducing vascular smooth muscle cell activation. Am. J. Pathol. 184: $2134-2143$. [Medline] [CrossRef]

7. Fehér, K. 2019. Single Stranded DNA Immune Modulators with Unmethylated CpG Motifs: Structure and Molecular Recognition by Toll-Like Receptor 9. Curr. Protein Pept. Sci. 20: 1060-1068. [Medline] [CrossRef]

8. Ferreira-Duarte, A. P., Pinheiro-Torres, A. S., Takeshita, W. M., Gushiken, V. O., Roncalho-Buck, I. A., Anhê, G. F. and DeSouza, I. A. 2020. Airway exposure to Staphylococcal enterotoxin type B (SEB) enhances the number and activity of bone marrow neutrophils via the release of multiple cytokines. Int. Immunopharmacol. 78: 106009. [Medline] [CrossRef]

9. Ferret-Bernard, S., Lacroix-Lamandé, S., Remot, A., Metton, C., Bernardet, N., Charley, B., Drouet, F. and Laurent, F. 2011. Mesenteric lymph 
node cells from neonates present a prominent IL-12 response to CpG oligodeoxynucleotide via an IL-15 feedback loop of amplification. Vet. Res. (Faisalabad) 42: 19. [Medline] [CrossRef]

10. Fonseca-Camarillo, G., Furuzawa-Carballeda, J., Granados, J. and Yamamoto-Furusho, J. K. 2014. Expression of interleukin (IL)-19 and IL-24 in inflammatory bowel disease patients: a cross-sectional study. Clin. Exp. Immunol. 177: 64-75. [Medline] [CrossRef]

11. Fujimoto, Y., Azuma, Y. T., Matsuo, Y., Kuwamura, M., Kuramoto, N., Miki, M., Azuma, N., Teramoto, M., Nishiyama, K., Izawa, T., Nakajima, H. and Takeuchi, T. 2017. Interleukin-19 contributes as a protective factor in experimental Th2-mediated colitis. Naunyn Schmiedebergs Arch. Pharmacol. 390: 261-268. [Medline] [CrossRef]

12. Fujimoto, Y., Fujita, T., Kuramoto, N., Kuwamura, M., Izawa, T., Nishiyama, K., Yoshida, N., Nakajima, H., Takeuchi, T. and Azuma, Y. T. 2018. The Role of Interleukin-19 in Contact Hypersensitivity. Biol. Pharm. Bull. 41: 182-189. [Medline] [CrossRef]

13. Gallagher, G., Dickensheets, H., Eskdale, J., Izotova, L. S., Mirochnitchenko, O. V., Peat, J. D., Vazquez, N., Pestka, S., Donnelly, R. P. and Kotenko, S. V. 2000. Cloning, expression and initial characterization of interleukin-19 (IL-19), a novel homologue of human interleukin-10 (IL-10). Genes Immun. 1: 442-450. [Medline] [CrossRef]

14. Ha, H. L., Wang, H., Claudio, E., Tang, W. and Siebenlist, U. 2020. IL-20-receptor signaling delimits IL-17 production in psoriatic inflammation. $J$. Invest. Dermatol. 140: 143-151.e3. [Medline] [CrossRef]

15. Hegde, A., Zhang, H., Moochhala, S. M. and Bhatia, M. 2007. Neurokinin-1 receptor antagonist treatment protects mice against lung injury in polymicrobial sepsis. J. Leukoc. Biol. 82: 678-685. [Medline] [CrossRef]

16. Horiuchi, H., Parajuli, B., Wang, Y., Azuma, Y. T., Mizuno, T., Takeuchi, H. and Suzumura, A. 2015. Interleukin-19 acts as a negative autocrine regulator of activated microglia. PLoS One 10: $\mathrm{e} 0118640$. [Medline] [CrossRef]

17. Hsing, C. H., Cheng, H. C., Hsu, Y. H., Chan, C. H., Yeh, C. H., Li, C. F. and Chang, M. S. 2012. Upregulated IL-19 in breast cancer promotes tumor progression and affects clinical outcome. Clin. Cancer Res. 18: 713-725. [Medline] [CrossRef]

18. Hsing, C. H., Chiu, C. J., Chang, L. Y., Hsu, C. C. and Chang, M. S. 2008. IL-19 is involved in the pathogenesis of endotoxic shock. Shock 29: 7-15. [Medline]

19. Hsu, Y. H., Li, H. H., Sung, J. M., Chen, W. T., Hou, Y. C. and Chang, M. S. 2013. Interleukin-19 mediates tissue damage in murine ischemic acute kidney injury. PLoS One 8: e56028. [Medline] [CrossRef]

20. Konrad, R. J., Higgs, R. E., Rodgers, G. H., Ming, W., Qian, Y. W., Bivi, N., Mack, J. K., Siegel, R. W. and Nickoloff, B. J. 2019. Assessment and clinical relevance of serum IL-19 levels in psoriasis and atopic dermatitis using a sensitive and specific novel immunoassay. Sci. Rep. 9: 5211. [Medline] [CrossRef]

21. Kumar, N. P., Moideen, K., Banurekha, V. V., Nair, D. and Babu, S. 2018. Modulation of Th1/Tc1 and Th17/Tc17 responses in pulmonary tuberculosis by IL-20 subfamily of cytokines. Cytokine 108: 190-196. [Medline] [CrossRef]

22. Kunz, S., Wolk, K., Witte, E., Witte, K., Doecke, W. D., Volk, H. D., Sterry, W., Asadullah, K. and Sabat, R. 2006. Interleukin (IL)-19, IL-20 and IL-24 are produced by and act on keratinocytes and are distinct from classical ILs. Exp. Dermatol. 15: 991-1004. [Medline] [CrossRef]

23. Liu, X., Zhou, H., Huang, X., Cui, J., Long, T., Xu, Y., Liu, H., Yu, R., Zhao, R., Luo, G., Huang, A., Liang, J. G. and Liang, P. 2016. A broad blockade of signaling from the IL-20 family of cytokines potently attenuates collagen-induced arthritis. J. Immunol. 197: 3029-3037. [Medline] [CrossRef]

24. Matsumoto, M. and Seya, T. 2008. TLR3: interferon induction by double-stranded RNA including poly(I:C). Adv. Drug Deliv. Rev. 60: 805-812. [Medline] [CrossRef]

25. Matsuo, Y., Azuma, Y. T., Kuwamura, M., Kuramoto, N., Nishiyama, K., Yoshida, N., Ikeda, Y., Fujimoto, Y., Nakajima, H. and Takeuchi, T. 2015. Interleukin 19 reduces inflammation in chemically induced experimental colitis. Int. Immunopharmacol. 29: 468-475. [Medline] [CrossRef]

26. Menon, J. N. and Bretscher, P. A. 1996. Characterization of the immunological memory state generated in mice susceptible to Leishmania major following exposure to low doses of L. major and resulting in resistance to a normally pathogenic challenge. Eur. J. Immunol. 26: 243-249. [Medline] [CrossRef]

27. Metelitsa, L. S., Wu, H. W., Wang, H., Yang, Y., Warsi, Z., Asgharzadeh, S., Groshen, S., Wilson, S. B. and Seeger, R. C. 2004. Natural killer T cells infiltrate neuroblastomas expressing the chemokine CCL2. J. Exp. Med. 199: 1213-1221. [Medline] [CrossRef]

28. Morokata, T., Ishikawa, J., Ida, K. and Yamada, T. 1999. C57BL/6 mice are more susceptible to antigen-induced pulmonary eosinophilia than $\mathrm{BALB} / \mathrm{c}$ mice, irrespective of systemic T helper 1/T helper 2 responses. Immunology 98: 345-351. [Medline] [CrossRef]

29. Ottaviani, C., Nasorri, F., Bedini, C., de Pità, O., Girolomoni, G. and Cavani, A. 2006. CD56brightCD16(-) NK cells accumulate in psoriatic skin in response to CXCL10 and CCL5 and exacerbate skin inflammation. Eur. J. Immunol. 36: 118-128. [Medline] [CrossRef]

30. Renckens, R., Roelofs, J. J., ter Horst, S. A., van 't Veer, C., Havik, S. R., Florquin, S., Wagenaar, G. T., Meijers, J. C. and van der Poll, T. 2005. Absence of thrombin-activatable fibrinolysis inhibitor protects against sepsis-induced liver injury in mice. J. Immunol. 175: 6764-6771. [Medline] [CrossRef]

31. Steinert, A., Linas, I., Kaya, B., Ibrahim, M., Schlitzer, A., Hruz, P., Radulovic, K., Terracciano, L., Macpherson, A. J. and Niess, J. H. 2017. The Stimulation of macrophages with TLR ligands supports increased IL-19 expression in inflammatory bowel disease patients and in colitis models. $J$. Immunol. 199: 2570-2584. [Medline] [CrossRef]

32. Weng, Y. H., Chen, W. Y., Lin, Y. L., Wang, J. Y. and Chang, M. S. 2019. Blocking IL-19 signaling ameliorates allergen-induced airway inflammation. Front. Immunol. 10: 968. [Medline] [CrossRef]

33. Wolk, K., Witte, K., Witte, E., Proesch, S., Schulze-Tanzil, G., Nasilowska, K., Thilo, J., Asadullah, K., Sterry, W., Volk, H. D. and Sabat, R. 2008. Maturing dendritic cells are an important source of IL-29 and IL-20 that may cooperatively increase the innate immunity of keratinocytes. $J$. Leukoc. Biol. 83: 1181-1193. [Medline] [CrossRef]

34. Zhao, X., Yin, L., Fang, L., Xu, L., Sun, P., Xu, M., Liu, K. and Peng, J. 2018. Protective effects of dioscin against systemic inflammatory response syndromevia adjusting TLR2/MyD88/NF-kb signal pathway. Int. Immunopharmacol. 65: 458-469. [Medline] [CrossRef] 